\title{
Aplikasi Arduino Uno Pada Modul Robot Manusia Sebagai Mediasi Pengajaran Desain, Narasi Dan Simulasi
}

\author{
Heny Ispur Pratiwi ${ }^{1, *}$, Prio Handoko ${ }^{2}$ \\ ${ }^{1}$ Department of Informatics, Universitas Pembangunan Jaya \\ South Tangerang, Banten 15413, Indonesia \\ 06hnmay@gmail.com \\ ${ }^{2}$ Department of Informatics, Universitas Pembangunan Jaya \\ South Tangerang, Banten 15413, Indonesia \\ prio.handoko@upj.ac.id
}

Received 29 July 2019, Revised 12 September 2019, Accepted 17 September 2019

\begin{abstract}
Robotic is an engineering study through concepts, design, assembly process and developing finished product. Integrated electronics, computer science, artificial intelligence, mechatronics and nanotechnology fields surface visual complexity, hence does not inspire students to get into the robotic field. Whereas this field could be inspiring for non engineering students. This research output is expected to base for basic embedded systems subjects on software and hardware enhanced to intelligence systems. Moreover, complex humanoid robot movements would forward continuing the emergence of artificial intelligence applications for robotic developments. humanoid robot module with C programming language of the Arduino Uno microcontroller resolves standard humanoid robot dynamic movements. Research and development methods stage to carry out quantitative and qualitative applications, such as design, implementation, integration and system testing, and survey. Questionaire was used as a tool to collect student responses for analysis and conclusion on observing imperfect look of device assembly, hence to be expected as a mediation or bridge to teaching robotics.
\end{abstract}

Keywords: Robotic, Servo, Arduino Uno, C programming

\begin{abstract}
Abstrak - Robotika adalah studi bidang teknik melalui konsep, desain, proses perakitan dan pengembangan hasil akhir produk. Sistem elektronik yang terintegrasi dengan ilmu komputer, kecerdasan buatan, mekatronik dan bidang nanoteknologi yang terlihat rumit, sehingga tidak menginspirasi siswa untuk menekuni bidang robotik. Padahal bidang ini bisa menjadi inspirasi bagi bahkan bagi mahasiswa non teknik. Luaran penelitian ini diharapkan menjadi dasar tambahan mata pelajaran sistem tanam pada perangkat lunak dan perangkat keras untuk ditingkatkan integrasi tersebut kedalam sistem intelijen. Selain itu, gerakan robot humanoid yang kompleks akan menjadi kelanjutan kemunculan aplikasi kecerdasan buatan untuk pengembangan robot. Modul robot humanoid ini dengan bahasa pemrograman $\mathrm{C}$ dari mikrokontroler Arduino Uno mampu membentuk dasar gerakan humanoid robot yang dinamis.Tahap metode penelitian dan pengembangan diterapkan untuk melaksanakan aplikasi kuantitatif dan kualitatif, seperti desain, implementasi, integrasi dan pengujian sistem, dan survei. Kuesioner digunakan sebagai alat untuk mengumpulkan tanggapan siswa sebagai analisis dan kesimpulan dari pengamatan siswa terhadap tampilan perangkat yang belum memiliki rakitan yang sempurna secara sengaja, sehingga bisa diharapkan berkembang sebagai mediasi atau jembatan untuk pengajaran robotika.
\end{abstract}

Kata Kunci: Robotika, Servo, Arduino Uno, C programming

\section{PENDAHULUAN}

Kreatifitas pengembangan sistem gerakan sebuah robot manusia di Universitas Pembangunan Jaya bisa dikatakan tidak banyak dilakukan, sehingga daya tarik teknologi ini belum bisa menginspirasi dosen dan mahasiswa untuk ikut andil dalam pengembangan tersebut. Salah satu penghambat daya tarik dan inspirasi terhadap teknologi robotik adalah ketiadaan sarana program riset untuk membangun format awal sistem basis robotik yang terwujud dan mudah di pelajari dan dikembangkan. Penelitian dosen pemula ini bisa menjadi sarana penorobos untuk menembus daya tarik dan inspirasi mahasiswa, sehingga secara konsep dasar, menghasilkan kepuasan pribadi dalam memahaminya.

Diawali dengan pengetahuan dasar cara pemrograman bahasa $\mathrm{C}$, yang sudah lekat dengan perangkat mikrokontroler Arduino, sebagai basis sistem untuk merancang bangun sistem tanam yang akan diimplementasikan pada modul robot manusia yang sudah di bangun. Persiapan sistem secara 
menyeluruh harus di kerjakan, pemisahan area dan fungsi harus dilakukan untuk melancarkan proses pemrograman perangkat lunak, uji coba setiap bagian dari setiap area dan fungsi tersebut juga harus dilakukan, dan akhirnya penyatuan atau integrasi seluruh sistem bisa menjadi ukuran tahap persentasi kesuksesan yang dicapai oleh sistem yang dibangun.

Praktik pengenalan robotik dalam proses pengajaran akademik sudah banyak dilakukan, namun belum tentu praktik tersebut menjadi effisien, karena seringkali ada jurang pemisah antara narasi dan simulasi. Modul robot manusia sebagai obyek dari penelitian ini, bisa sebagai alat kognisi dan sebagai sarana pengajaran, pengembangan serta pembinaan siswa. Setiap tahap pengerjaan, pengembangan dan pengintegrasian perangkat lunak dan perangkat keras diharapkan akan memberi pengalaman yang unik pada siswa yang baru memulai mengeksploitasi obyek penelitian tersebut. Penelitian ini dilakukan untuk penerobosan proses akademis, selanjutnya bisa membuka kemungkinan yang luas untuk dosen dan mahasiswa dari beragam bidang studi, jadi bukan hanya bidang studi yang berorientasi teknologi. Lingkaran substansi dari beragam bidang studi keilmuan diharapkan akan bermunculan, sehingga robotik makin menjadi sebuah pilihan prioritas untuk kelanjutan pengembangan masyarakat yang maju.

Robotik adalah salah satu bidang studi teknik rekayasa yang melibatkan konsep, desain, perakitan dan operasional atau implementasi produk yang di hasilkan. Keterlibatan bidang studi elektronik, ilmu computer, kecerdasan buatan, mekatronik dan teknologi nano menciptakan kompleksitas yang bisa memunculkan kesan serius dan sulit, sehingga akhirnya tidak menginspirasi siswa untuk terjun ke bidang robotik. Padahal bidang ini bisa membuka peluang luas untuk dipelajari bahkan untuk jurusan yang non teknik.

Hasil penelitian ditujukan untuk bisa dijadikan basis pendidikan sistem tanam, yang melibatkan perangkat lunak dan keras, sebagai salah satu sarana implementasi sistem cerdas yang menjadi visi dan misi Program Studi Informatika di Universitas Pembangunan Jaya. Selain itu, hasil penelitian ini akan menjadi awal pengembangan pembelajaran algoritma gerakan robot manusia yang lebih beragam dan berlanjut dengan aplikasi kecerdasan buatan atau penambahan sistem tanam dengan aplikasi teknologi terkini.

Permasalahan yang dapat dirumuskan adalah bagaimana aplikasi mikrokontroler Arduino Uno pada modul robot manusia dapat memudahkan pembelajaran robotika dengan menjembatani totalitas pengertian antara desain, narasi dan simulasi.

Dibandingkan dengan beberapa penelitian yang sudah dilakukan sebelumnya adalah bahwa penelitian ini merupakan terobosan pengajaran robotika dan Internet of Things yang bisa menjembatani antara desain, narasi dan simulasi, sehingga membuka kemunculan penelitian-penelitian lanjutan dari bidang studi yang beragam di Perguruan Tinggi. Terobosan ini dinyatakan dengan perspektif secara faktual bahwa jurusan Informatika yang secara konvensional hanya berurusan dengan software, dan perkembangan ilmu pengetahuan dan teknologi menuntut untuk melihat robotika sebagai peminatan yang serius, sedangkan kondisi kesiapan sikap untuk berurusan dengan hardware dan perangkat electronic masih dalam tingkat sikap canggung terhadap keunggulan peminatan ini, sehingga terobosan ini bisa menjadi alat sosialisasi Internet of Things dan akhirnya menjadi mediasi bermanfaat terhadap Artificial Intelligence dilanjutkan ke bidang Deep Learning.

Diawali dengan deskripsi dibagian pendahuluan untuk memberi latar belakang alasan penelitian dilakukan. Selanjutnya tujuan penelitian bisa dicapai dengan melakukan kajian dan analisa terhadap data yang di peroleh dengan menggunakan metodology yang diterapkan. Kesimpulan merangkum hasil kajian dan analisa data yang didapatkan dan memunculkan beberapa topik pengembangan sebagai penelitian berikutnya.

\section{KAJIAN PUSTAKA}

\section{Mikrokontroler Arduino}

Mikrokontroler adalah semacam komputer kecil yang terintegrasi sebagai kesatuan sistem rancang bangun yang terdiri dari mikroprosesor, penyimpan data, dan komponen elektronik sebagai akses masukan dan luaran data. Arduino adalah nama produk mikrokontroler yang sudah di perlengkapi dengan komponen tambahan, contohnya mikrokontroler sudah di rancang bangun untuk sistem tanam dengan bahasa pemrograman $\mathrm{C}$, sehingga memudahkan proses rancang bangun sebuah project.

Arduino Uno adalah mikrokontroler yang bisa berposisi sebagai open-source. Dilengkapi dengan ATmega328P, empat belas pin input/output, dimana enam dari pin tersebut dapat digunakan sebagai keluaran Pulse Width-Modulation (PWM), enam input analog, satu akses koneksi USB (Universal Serial Bus), Kabel power, dan tombol reset. Untuk mulai melakukan pemprograman, diperlukan pengunduhan perangkat lunak dari link http://arduino.cc/en/Main/Software. Perangkat lunak ini sudah di rancang bangun untuk beradaptasi atau bisa menterjemahkan elemen-elemen bahasa pemrograman C (Santoso, 2013).

\section{Integrated Development Environment (IDE)}

IDE, seperti ditunjukan gambar 2 berikut, adalah format dan ruang untuk merancang bangun suatu project, sedangkan bagian-bagian dari IDE tersebut seperti berikut (dari kiri ke kanan): Compile atau kompilasi, fungsi ini adalah proses yang dilakukan sebelum hasil final pemorgraman dikirim ke sistem eksekusi. 


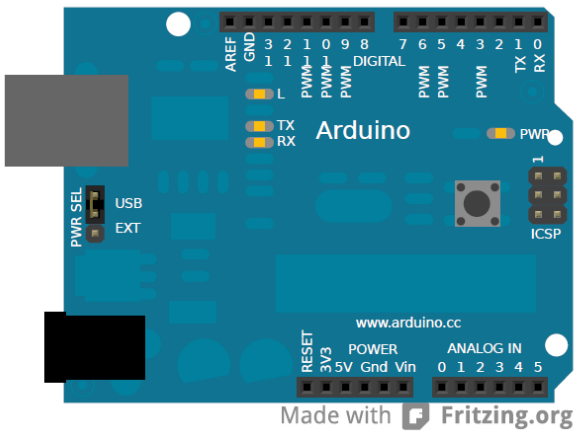

Gambar 1. Mikrokontroler Arduino

Tahapan proses ini melakukan penerjemahan instruksi, yang di pakai dalam pengkodean tersebut, sehingga bisa terbaca oleh sistem. Stop adalah fungsi untuk memberhentikan proses kompilasi bila diperlukan. Create New Sketch adalah fungsi untuk menciptakan layar baru untuk project baru. Open Existing Sketch adalah fungsi untuk membuka suatu arsip, yang disimpan dalam ruang penyimpan data, dari pengerjaan project yang pernah dilakukan. Save Sketch adalah fungsi untuk menyimpan perubahanperubahan terhadap project yang sedang dikerjakan. Upload to Board adalah fungsi untuk mengunggah hasil final pemrograman bila dianggap sudah memadai dengan luaran yang dihasilkan. Tab Button adalah fungsi untuk memperbanyak arsip pengerjaan di layar. Sketch Editor adalah halaman yang berfungsi untuk proses pemrograman dan pengubahan. Text Console adalah layar yang berfungsi untuk memperlihatkan IDE yang sedang diproses, dimana semua kesalahan-kesalahan yang dilakukan akan diberitahu oleh sistem. Line Number adalah fungsi layar yang mempermudah pengguna mengetahui lokasi kesalahan-kesalahan yang diberitahu sistem tersebut dengan penanda nomor baris di layar.

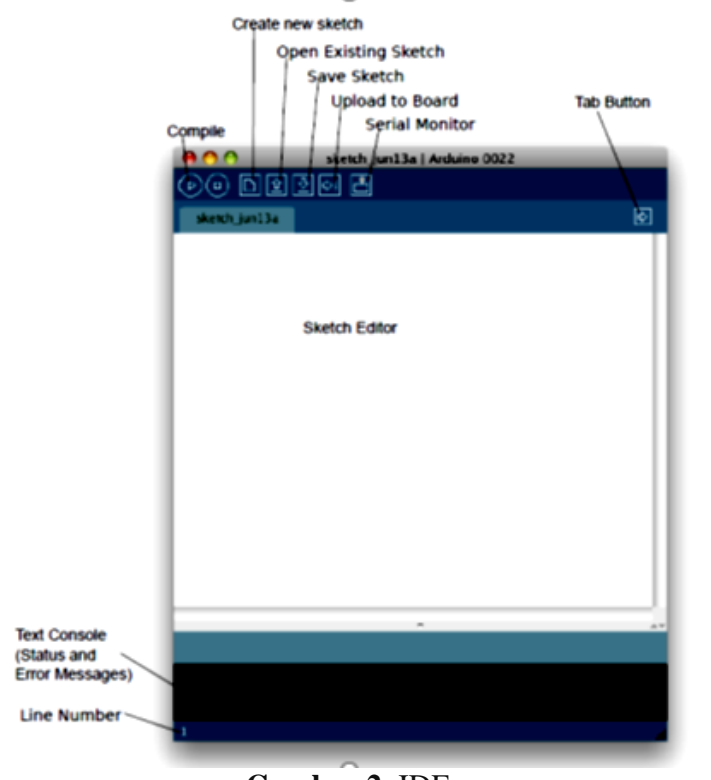

Gambar 2. IDE

\section{Servo}

Servo adalah sebuah motor yang bisa menerima perintah untuk melakukan gerakan dengan sudut derajat antara derajat 0 sampai 180, seperti digambarkan pada gambar 3. Servo memiliki tiga pin, biasanya ditandai oleh kode warna, biasanya power (sumber tenaga listrik) ditandai dengan warna merah, ground biasanya ditandai dengan warna hitam, dan signal biasanya ditandai dengan warna putih atau warna lain. Gambar 4 menampilkan bagan komponen pada servo (https://www.ia.omron.com).
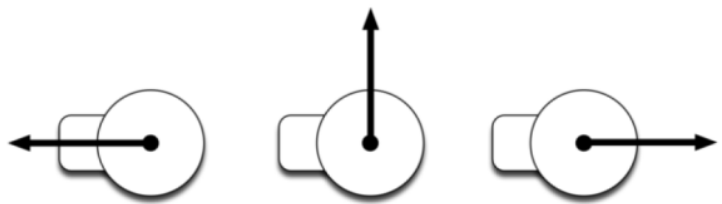

Gambar 2. Arah gerakan dari 0 sampai 180 derajat
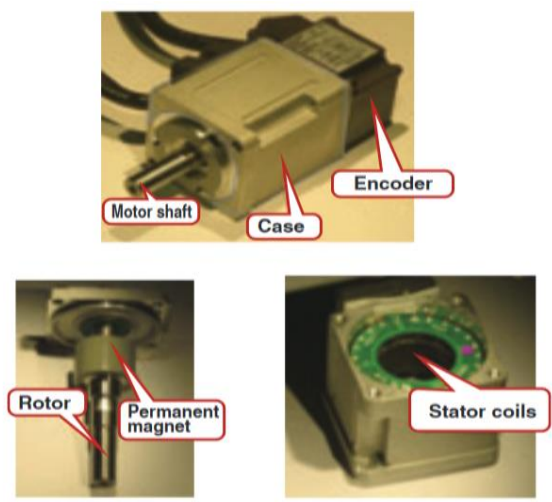

Gambar 3. Servo

\section{METODE PENELITIAN}

\section{Metode Pengembangan Prototyping}

Model pengembangan prototyping merupakan sebuah model pengembangan sistem yang secara aktif melibatkan pengguna untuk menentukan kesesuaian pengembang menginterpretasikan kebutuhan (objectives) pengguna (Pressman, 2010). Secara umum, model prototyping ini dipilih didasarkan pada minimnya informasi pengguna mengenai sistem yang dibutuhkan. Pengguna hanya menginformasikan kebutuhannya secara garis besar dan tidak terinci, sehingga pengembang harus menarik beberapa asumsi mengenai kebutuhan rinci pengguna.

\section{Metode Deskriptif dengan Pendekatan Kualitatif}

Pendekatan Kualitatif dilakukan dan disesuaikan dengan tujuan pokok penelitian, yaitu mendeskripsikan dan menganalisis mengenai latar belakang banyak mahasiswa yang tidak memiliki konsep pemahaman yang penuh tentang matakuliah robotik atau sistem tanam, yang seringkali tirai tipis diantara kedua bidang tersebut membuat mahasiswa membuat kesimpulan yang salah tanpa ada pembimbingan selanjutnya. 


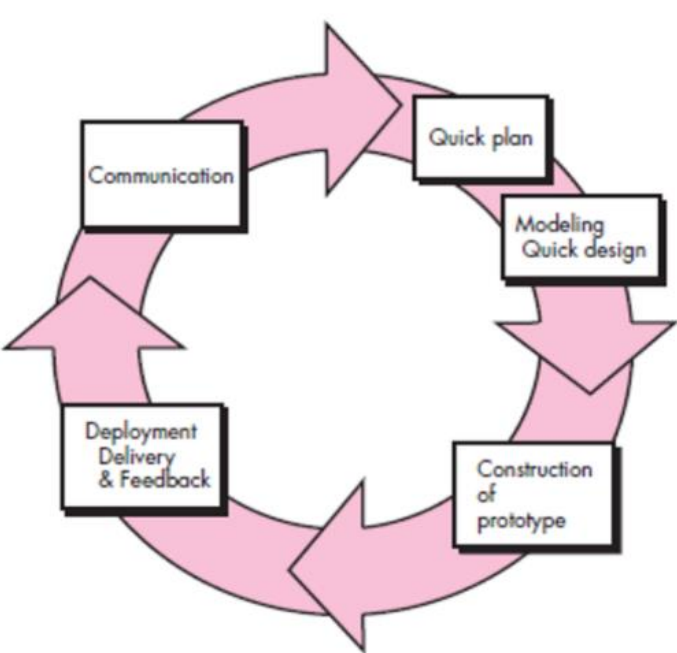

Gambar 5. Model Pengembangan Prototyping (Pressman, 2010)

Pada pendekatan penelitian kualitatif ini akan lebih menekankan segi proses daripada hasil. Kuesioner merupakan salah satu media dalam penerapan pendekatan kualitatif, sedangkan hasil yang didapatkan adalah sebagai data untuk di observasi dan dianalisis latar belakang jawaban tersebut muncul dan bagaimana proses para responden menjawab pertanyaan yang diberikan. Selama proses tersebut setiap langkah observasi yang dilakukan untuk menggali informasi yang berkenaan dengan kompetensi responden akan diteliti, sehingga bisa diasumsikan data yang didapat sudah melalui tahap validitas yang diperlukan, sehingga bisa dipercaya serta lebih bermakna. Penelitian kualitatif adalah jenis penelitian yang temuan-temuannya tidak diperoleh melalui prosedur statistik atau bentuk hitungan lainnya (Imam Gunawan, 2013).

Kuesioner yang dilakukan adalah sebagai terapan dalam penelitian kualitatif yang sesuai adalah secara umum dengan wawancara, pengamatan, dan pemanfaatan dokumen (Lexy J. Moleong, 2012). Adapun data yang dihasilkan akan bersifat deskriptif yaitu hasil penelitian yang menggambarkan data informasi yang berdasarkan fakta yang diperoleh dilapangan. Kesimpulan ditampilkan secara deskriptif menggambarkan fenomena yang ada, baik fenomena yang bersifat ilmiah ataupun rekayasa manusia. Penelitian kualitatif ini membantu untuk mengkaji bentuk, aktivitas, karakteristik, perubahan, hubungan, kesamaan dan perbedaannya dengan fenomena lain. Proses hasil akhir digunakan untuk mendeskripsikan dan menganalisa fenomena, peristiwa, aktivitas sosial, sikap, kepercayaan, persepsi secara individual atau kelompok (Nana Syaodih Sukmadinata, 2009).

\section{Metode Pengumpulan Data}

Sebelum pengumpulan data, peneliti langsung melakukan simulasi terhadap perangkat yang sudah jadi, lalu mengamati komponen perangkat serta gerakan yang sudah diatur dan selanjutnya menyusun beberapa pertanyaan dalam sebuah kuesioner untuk memperoleh data yang dibutuhkan. Pengisian kuesioner dilakukan langsung oleh mahasiswa jurusan Informatika, Universitas Pembangunan Jaya. Dalam melakukan pengisian kuesioner, mahasiswa dituntut oleh pertanyaan yang disajikan untuk mengamati dan simulasi perangkat yang diberikan. Sedangkan observasi dilakukan langsung oleh peneliti dengan mencatat perilaku setiap responden sebelum, selama dan sesudah pengisian kuesioner.

\section{HASIL DAN ANALISIS}

Perancangan dan perakitan hardware dan software pada dasarnya ditujukan untuk menunjang obyektifitas penelitian yaitu sebagai mediasi kuesioner yang dibagikan pada siswa. Hasil dari perancangan dan perakitan telah berhasil dan sudah bisa diterapkan untuk proses pengumpulan data dari kuesioner yang di isi. Gambar 6 adalah hasil perancangan dan perakitan hardware dengan pergerakan-pergerakan tangan dan kaki dari pemrograman sofware berbahasa C.

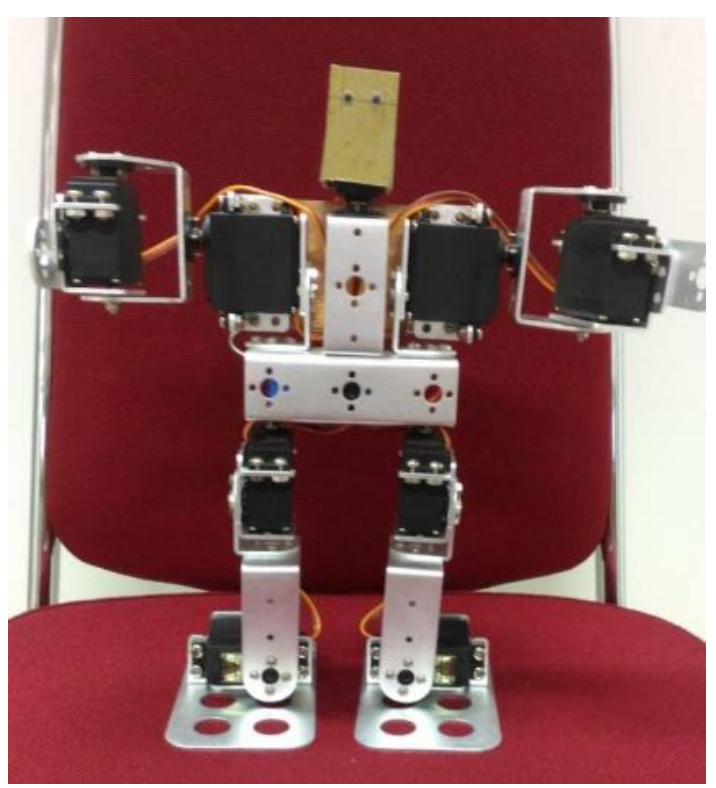

Gambar 6. Humanoid robot

Kuesioner sudah dibagikan kepada 55 responden yang latarbelakang para responden adalah para mahasiswa beragam angkatan dan jurusan, adapaun para responden dari jurusan Informatika adalah responden yang belum pernah mengambil matakuliah robotika namun sudah menjalani satu setengah semester bidang studi Informatika. Tabel 1 adalah ringkasan hasil penghitungan data dari kuesioner yang dibagikan dan diisi.

Pada topik pertanyaan nomor 1, yang paling menonjol pada topik kesukaan mahasiswa baru pada satu matakuliah adalah dari minat dan bakat yang ada pada diri sendiri yang terwakili oleh persentase terbesar yaitu $40 \%$, yang bukan lagi sesuatu penemuan yang baru atau dalam kata lain hal ini secara universal akan berlaku untuk setiap individu. 
Namun yang hasil persentase penghitungan yang seimbang adalah antara dosen pengampu dan materi yang mudah dengan angka $25 \%$ untuk masing-masing pilihan. Tentang dosen pengampu dan materi yang mudah bisa dibilang masuk akal, namun hal ini bisa menimbulkan isu yang sifatnya kontroversial.

Tabel 1. Topik Pertanyaan $1-3$

\begin{tabular}{lll}
\hline No. & Topik Pertanyaan & $\begin{array}{c}\text { Total } \\
\text { Persentase }\end{array}$ \\
\hline 1. & \multicolumn{2}{l}{ Menyukai suatu matakuliah } \\
karena: & \\
& (i). dosen pengampu & (i). $25 \%$ \\
(ii). materi yang mudah & (ii). $25 \%$ \\
(iii). nilai yang murah & (iii) $10 \%$ \\
& (iv). Alami memang anda & (iv). $40 \%$ \\
& suka
\end{tabular}

2. Gambaran jelas tentang isi matakuliahyang bersangkutan dengan perangkat:

$\begin{array}{rlr}\text { (i). } & \text { Mikrokontroler } & \text { (ii). } 35 \% \\ \text { (ii). } & \text { Sistem tanam } & \text { (iii). } 46 \% \\ \text { (iii). } & \text { Robotika } & \text { (iv). } 4 \% \\ \text { (iv). } & \text { Tidak Tahu } & \end{array}$

3. Tentang Pemahaman Perangkat yang disediakan

$\begin{array}{rlr}\text { (i). } & \text { Mikrokontroler } & \text { (i). } 25 \% \\ \text { (ii). } & \text { Sistem tanam } & \text { (ii). } 35 \% \\ \text { (iii). } & \text { Robotika } & \text { (iii). } 40 \%\end{array}$

4. Tentang Pemahaman Perangkat yang disediakan (2 pilihan):

$\begin{aligned} \text { (i). } & \text { Mikrokontroler } \\ \text { (ii). } & \text { Sistem tanam } \\ \text { (iii). } & \text { Robotika }\end{aligned}$

5. Logika dan Algoritma dasardasar operasi/gerakan yang BISA dan TIDAK BISA dilakukan oleh perangkat tersebut.

6. Ketidak layakan pada Software atau hardware atau menjawab keduanya

\section{$90 \%$} tidak jawab apa yang di tanyakan

$97 \%$ menjawab
Secara titik pandang praktik, bila dosen pengampunya berkualifikasi atau sudah berpengalaman dalam bidang yang diajarkan, maka materi yang disampaikan di kelas menjadi mudah untuk dimengerti. Namun bisa juga terjadi sebaliknya, yaitu dosen pengampu tidak berkualifikasi atau berpengalaman sehingga materi yang diajarkan hanya yang mudah saja atau dalam lingkup elementary. Terakhir angka persentase $10 \%$ pada nilai yang murah berada pada tingkat terendah dibanding dengan pilihan lain, namun $10 \%$ adalah jumlah yang tidak bisa diabaikan karena ini cukup besar untuk bisa bersaing dengan pilihan dosen pengampu dan materi yang mudah tersebut diatas.

Pada topik pertanyaan nomor 2, yaitu gambaran jelas tentang isi matakuliah yang bersangkutan dengan perangkat, jawaban pilihan robotik berada pada tingkat tertinggi yaitu $46 \%$ yang pada dasarnya amat masuk akal, karena perangkat yang diberikan secara visual berbentuk robot manusia. Sedangkan responden yang menjawab mikrokontroler atau sistem tanam, beberapa dari mereka melihat ada sistem yang mengoperasikan perangkat. Adapun persentase 4\% dikategorikan tidak tahu karena kuesioner tidak di isi di bagian tersebut.

Pada topik pertanyaan nomor 3, yaitu tentang pemahaman perangkat yang disediakan dengan permintaan untuk menjawab dengan satu pilihan, persentase terbesar adalah $40 \%$ amat sangat masuk akal. Topik pertanyaan nomor 3 hampir sama dengan topik pertanyaan nomor 2 , hanya saja nomor 3 lebih menekankan pada pemahaman pada perangkat yang dipakai, bukan gambaran matakuliah perangkat tersebut. Yang menarik adalah kesinambungan topik pertanyaan nomor 3 ke nomor 4 yang menuntut responden untuk menjawab dengan dua pilihan, 55\% responden hanya menjawab dengan satu pilihan. Dalam hal ini bisa dimengerti bahwa separuh dari responden belum mengerti terminologi sistem tanam.

Pada topik pertanyaan nomor 5, yaitu tentang logika dan algoritma dasar-dasar operasi/gerakan yang BISA dan TIDAK BISA dilakukan oleh perangkat yang disediakan, angka persentase $90 \%$ responden adalah tidak menjawab dengan benar. Ini menjadi sesuatu yang spesifik untuk diperhatikan, karena peneliti terlibat langsung dalam proses mendistribusikan kuesioner dan melakukan pendampingan selama responden mengisi jawaban setiap topik pertanyaan. Peneliti melakukan observasi perilaku responden selama proses menjawab topik pertanyaan nomor 5, beberapa dari mereka melihat secara pintas, beberapa mensimulasi ulang perangkat, beberapa bertanya responden yang lain tentang jawaban yang harus dituliskan, beberapa mencoba merenungkan sesuatu, namun tidak ada yang bertanya pada peneliti untuk memahami apa yang ditanyakan dan jawaban seperti apa yang diharapkan, walau sudah tercetak secara jelas pada kuesioner. Sebagai salah satu contoh yang menyolok adalah responden menjawab dengan menyebutkan gerakan-gerakan yang tidak bisa dilakukan oleh perangkat pada topik pertanyaan yang menuntut jawaban yang BISA dilakukan dan sebaliknya.

Pada topik pertanyaan nomor 6 , tentang ketidak layakan pada Software atau hardware atau keduanya, angka persentase $97 \%$ menjawab kedua Software dan Hardware tidak layak, dalam arti bahwa perangkat tidak mencapai kelayakan yang di harapkan karena kedua komponen tersebut. Jawaban ini bisa diterima sebagai jawaban yang benar. 


\section{KESIMPULAN}

\section{Rencana Tahapan Berikutnya}

Disebutkan pada perumusan masalah yaitu bagaimana aplikasi Arduino Uno pada modul robot manusia dapat memudahkan pembelajaran robotik dengan menjembatani pengertian mutlak antara desain, narasi dan simulasi. Kuesioner yang dirancang dan dibagikan untuk diisi secara sukarela tentang perangkat yang sudah berhasil dibangun telah memunculkan hasil yang menjembatani pengertian tentang desain, narasi dan simulasi terhadap pembelajaran robotika. Pertanyaan-pertanyaan pada kuesioner telah membuat para siswa berpikir untuk menjawab dan sebelumnya melakukan observasi sejenak terhadap perangkat robotik yang disediakan. Ketidak sempurnaan perangkat software dan hardware yang dibangun membuat para responden memiliki keinginan untuk menyempurnakan yang belum ditanamkan pada sistem, dan inilah yang diharapkan oleh peneliti.

Untuk menjembatani keinginan tersebut, bisa disiapkan rencana tahapan berikutnya yang bisa menampilkan bagian dari pemrograman yang sudah ada dan menawarkan pertanyaan tambahan pada kuesioner tentang pengembangan apa yang harus dilakukan pada bagian pemrograman yang disebutkan tersebut atau bisa juga dilakukan pada bagian penyempurnaan perangkat hardware.

Rencana tahapan pada perangkat berikutnya bisa dilakukan pengembangan software atau perangkat lunak dengan melengkapi gerakan-gerakan setiap komponen yang sudah terpasang, sehingga lebih menarik siswa secara simulasi dan visual. Selanjutnya juga menjadi landasan pengembangan Internet of Things dengan menerapkan efek suara atau sound effect dan memberi pembelajaran serta pemahaman tentang pengembangan yang bisa dilakukan mengikuti teknologi yang ada sekarang.

\section{Keterbatasan}

Data yang diperoleh dalam mendistribusikan kuesioner belum bisa dikatakan memuaskan peneliti untuk merepresentasikan hasil luaran penelitian ini dengan mempertimbangkan keterbatasan yang mungkin mempengaruhi hasil penelitian, diantaranya adalah:

1. Mayoritas responden hanya dari mahasiswa baru, sedangkan bisa diperluas dan diterapkan juga ke siswa-siswa SMA atau SMK.

2. Keterbatasan peluang untuk mencari waktu responden.

3. Selain itu masih terdapat banyak keterbatasan lainnya yang tidak disadari oleh peneliti, contohnya perangkat yang diberikan tidak sepenuhnya bisa mengantisipasi antusiasme beberapa responden.

4. Hasil penganalisaan data yang kualitatif perlu memikirkan penyaringan lebih dalam terhadap responden yang diminta untuk mengisi kuesioner yang dibuat.

\section{DAFTAR PUSTAKA}

Gunawan, I. (2013), Metode penelitian kualitatif, teori dan praktik, Jakarta: BumiAksara.

Moleong, L. J. (2012), Metodologi penelitian kualitatif, Bandung: PT. Remaja Rosdakarya.

Ospennikova, E., Ershov, M. \& Iljin, I. (2015), Educational robotics as an inovative educational technology, Procedia - Social and Behavioral Sciences, 214, 18 26.

Pressman, S. R. (2010), Software Engineering: a Practitioners Approach, Seventh Edition, The Mc Graw Hill Companies.

Giuseppe, A. \& Martina, P. (2012), Educational robotics between narration and simulation, Procedia - Social and Behavioral Sciences, 51, 104-109.

Santoso, A. B. (2013). Pembuatan otomasi pengaturan kereta api, pengereman, dan palang pintu pada rel kereta api mainan berbasis mikrokontroler. Jurnal Ilmiah Teknik Mesin, 1(1), 16 - 23.

Smit, A. G. (2011), Introduction to Arduino, diakses dari http://www.introarduino.com [20 Juli 2018]

Sukmadinata, N. S. (2009), Metode penelitian pendidikan, Bandung: Remaja Rosdakarya

Technical Explanation for Servomotors and Servo Drives Available:https://www.ia.omron.com/data_pdf/guide /14/servo_tg_e_1_1.pdf.

Trianni, V. (2014), Evolutionary robotics: model or design, Frontiers in Robotics and AI, https://doi.org/10.3389/frobt.2014.00013.

Virgala, M., Kelemen, M., Varga \& Kurylo, P. (2014), Analyzing, Modeling and simulation of humanoid robot hand motion, Procedia Engineering, 96, 489499.

Yusoff, M. A. K., Samin, R.E. \& Ibrahim, B. S. K. (2012), Wireless mobile robotic arm, Procedia Engineering, 41(7), 1072-1078. 